\title{
Seasonal Abundance of Thrips, Thrips tabaci Lindeman and its Natural Enemies on Kharif Onion
}

\author{
Deepika Yadav*, S.K. Khinchi, Purushotam Sharma and Hitesh Jangir \\ Department of Agricultural Entomology, S.K.N. College of Agriculture Jobner; \\ Jaipur 303328, India \\ *Corresponding author
}

\section{A B S T R A C T}

\section{Keywords}

Thrips tabaci, Natural enemies, Kharif onion, C. septempunctata

Article Info

Accepted:

12 January 2019

Available Online:

10 February 2019
The investigations on Seasonal Abundance of thrips, Thrips tabaci Lindemen on Kharif onion and Its Management through Insecticides" were conducted at Horticulture farm, S.K.N. College of Agriculture, Jobner during Kharif, 2016. The incidence of thrips, T. tabaci on onion was commenced in the second week of August and reached to its peak in the second week of September. Whereas, the predator, Coccinella septempunctata Linn. was commenced in the second week of August and reached to maximum in the third week of September. The temperature and relative humidity had non significant correlation with thrips incidence on onion crop whereas, predator $C$. septempunctata possess significant positive correlation $(\mathrm{r}=0.726)$.

\section{Introduction}

Onion, Allium cepa L. belongs to the family Alliaceae, is a biennial vegetable grown annually in temperate zone. Onion is one of the oldest edible food sources known to humankind, used as salad, recipes, mouthwatering gravies and curries. It has also been used in the traditional Ayurvedic medicines. Onions are very low in calories (just 40 calories per $100 \mathrm{~g}$ ) and fat rich in soluble dietary fibre. Phyto-chemical compounds Allium and Allyl propyl disulphide in the onions convert into Allicin for reducing blood vessel stiffness by releasing nitric oxide (NO)and there by brings reduction in the total blood pressure (Kumar, 2016). They are also a good source of antioxidant flavonoid quercetin, which is found to have anticarcinogenic, anti-inflammatory, and antidiabetic functions. They are good in antioxidant vitamin, vitamin- $\mathrm{C}$ and minerals. Onion contains about energy 2 per cent, carbohydrates 7 per cent, protein 2 per cent, fat 0.5 per cent, vitamin C 12 per cent and minerals 3.21 per cent. India is the second largest producer of onion in the world next after China but the productivity of onion in India is very low.

Thrips infest onion crop throughout the crop seasons. However, there was significant 
variation in thrips numbers between the crop seasons. Dry weather $(30.3 \mathrm{~mm}$ rainfall) with moderately high temperatures $\left(15.6-28.20^{\circ} \mathrm{C}\right)$ increased thrips population, while wet season (391mm rainfall) with moderately high relative humidity was negatively correlated with thrips population (Waiganjo, 2008).

\section{Materials and Methods}

The present investigations were conducted at Horticulture farm, S.K.N. College of Agriculture, Jobner (Rajasthan) on onion crop during the Kharif, 2016. Jobner is situated on longitude of 75.28 East latitude, 26.26 North latitude and at an elevation of $427 \mathrm{~m}$ above mean sea level (MSL) in Jaipur district of Rajasthan. The alluvial soils are present in Western and North-western parts of Jaipur, whereas, Sierozones are present in Eastern parts of the district.

To record the seasonal abundance of thrips, $T$. tabaci and its natural enemies on kharif onion crop, the bulb of onion variety Agrifound Dark Red of onion was sown in the mid July, 2016 , in five plots of $1.5 \times 1.5 \mathrm{~m}^{2}$ size, keeping row to row and plant to plant distance of $15 \times 10 \mathrm{~cm}$., respectively. The observation of thrips, T. tabaci and its natural enemies on onion crop were recorded right from their appearance to harvesting of the crop at weekly interval. The populations of thrips, $T$. tabaci were recorded in the early morning hours. Ten plants were randomly selected and tagged in each plot. The thrips were tapped on the white sheet and the populations were counted by naked eyes (Swami et al., 2013) or by using magnifying lens (Kumawat, 2009). The populations of natural enemies were also recorded on the same plants.

\section{Results and Discussion}

During the field experimentation, the incidence of thrips commenced in the first week of August (2.64 thrips/ plant) which gradually increased and reached to peak in the second week of September (31.32 thrips/ plant) at $34.9^{\circ} \mathrm{C}$ maximum, $22.4^{0} \mathrm{C}$ minimum temperature and 54.0 per cent relative humidity being, the most favourbale for buildup of population thereafter, thrips population declined and completely disappeared in the second week of October. The present finding are partial agreement with those of Anonymous (2001) reported that population of thrips on onion reached to maximum in August during Kharif season and touched the lowest in October. Chhatrola et al., (2003) reported that thrips population was active throughout the season on onion crop. Neergude et al., (2014) reported that seasonal incidence of thrips in Kharif season especially during August to October, support the above findings (Table 1 and 2).

The weather parameters viz., maximum and minimum temperature, relative humidity and rainfall play a significant role in planning the pest management schedules. In the present study the incidence of thrips was not affected by weather parameters significantly however, temperature and relative humidity, rainfall showed non significant positive and negative correlation, respectively with thrips incidence on onion crop. The present results are in agreement with those of Ghosh et al., (2005) who reported that relative humidity had non significant correlation with thrips incidence on onion crop however, temperature showed significant positive correlation. Chhatrola et al., (2003) reported that temperature had non significant correlation with thrips population and relative humidity had significant negative correlation, support the present findings.

The present study also corroborate with those of Domiciano et al., (1993) who reported that thrips population in onion crop was negatively correlated with relative humidity and positively correlated with temperature. 
Table.1 Seasonal abundance of onion thrips, T. tabaci on onion crop in relation to environmental factors during Kharif, 2016

\begin{tabular}{|c|c|c|c|c|c|c|c|c|}
\hline \multirow[t]{2}{*}{ S.No. } & \multirow{2}{*}{$\begin{array}{c}\text { Standard } \\
\begin{array}{c}\text { Meteoro } \\
\text { logical }\end{array} \\
\text { Week } \\
\text { (SMW) }\end{array}$} & \multirow{2}{*}{$\begin{array}{c}\text { Date of } \\
\text { observations }\end{array}$} & \multirow{2}{*}{$\begin{array}{c}\text { Mean } \\
\text { population } \\
\text { of thrips } \\
\text { (per plant) }\end{array}$} & \multirow{2}{*}{$\begin{array}{c}\text { Mean population } \\
\text { of } C \text {. } \\
\text { septempunctata } \\
\text { Linn. (per plot) }\end{array}$} & \multicolumn{2}{|c|}{ Temperature $\left({ }^{0} \mathrm{C}\right)$} & \multirow{2}{*}{$\begin{array}{l}\text { Relative } \\
\text { humidity } \\
\qquad(\%)\end{array}$} & \multirow{2}{*}{$\begin{array}{c}\text { Rain } \\
\text { fall } \\
(\mathbf{m m})\end{array}$} \\
\hline & & & & & Maximum & Minimum & & \\
\hline 1 & 32 & 08.08 .17 & 2.64 & 0.00 & 31.9 & 24.9 & 81.5 & 012.0 \\
\hline 2 & 33 & 15.08 .17 & 6.12 & 0.12 & 31.9 & 24.2 & 79 & 003.8 \\
\hline 3 & 34 & 22.08 .17 & 13.20 & 1.40 & 30.5 & 24.4 & 69 & 017.4 \\
\hline 4 & 35 & 29.09 .17 & 21.56 & $2 . .20$ & 32.7 & 24.4 & 63 & 016.6 \\
\hline 5 & 36 & 05.09 .17 & 28.32 & 2.60 & 32.3 & 22.5 & 60 & 000.0 \\
\hline 6 & 37 & 12.09 .17 & 31.32 & 3.40 & 34.9 & 22.4 & 54 & 000.0 \\
\hline 7 & 38 & 19.09 .17 & 29.12 & 2.80 & 37.9 & 23.3 & 67 & 000.0 \\
\hline 8 & 39 & 26.10 .17 & 26.00 & 2.00 & 37.1 & 22.7 & 53 & 000.0 \\
\hline 9 & 40 & 03.10 .17 & 18.28 & 1.40 & 34.3 & 23.6 & 41 & 013.2 \\
\hline 10 & 41 & 10.10 .17 & 9.12 & 1.20 & 35.2 & 20.6 & 43 & 000.0 \\
\hline & & & & & & & & \\
\hline
\end{tabular}

Table. 2 Correlation coefficient of biotic/ abiotic factors with mean thrips population

\begin{tabular}{|c|c|c|c|c|c|}
\hline \multirow{2}{*}{$\begin{array}{l}\text { Biotic/ } \\
\text { Abiotic } \\
\text { factors : }\end{array}$} & \multirow{2}{*}{$\begin{array}{c}\text { Mean } \\
\text { Coccinella } \\
\text { septempunctata } \\
\text { Linn. }\end{array}$} & \multicolumn{2}{|c|}{ Temperature $\left({ }^{0} \mathrm{C}\right)$} & \multirow{2}{*}{$\begin{array}{c}\text { Relative } \\
\text { Humidity (\%) }\end{array}$} & \multirow{2}{*}{$\begin{array}{c}\text { Rainfall } \\
\text { (mm) }\end{array}$} \\
\hline & & Maximum & Minimum & & \\
\hline $\begin{array}{c}\text { Correlation } \\
\text { with }\end{array}$ & & & & & \\
\hline mean thrips & 0.961 & 0.543 & -0.314 & -0.398 & -0.407 \\
\hline population: & & & & & \\
\hline
\end{tabular}

The biotic factors particularly coccinellid predators played a significant role in reducing the infestation of sucking pests. In the present investigation, coccinellid predator, Coccinella septempunctata Linn. was first observed in the third week of August (0.12/ ten plant) and reached maximum during third week of September (3.4/ ten plant). The population persisted as long as the thrips population was observed on the crop. The population of $C$. septempunctata was significant positively correlated $(r=0.961)$ with thrips population. The present finding partially corroborate with that of Kadri and Goud (2005) who reported that coccinellids were major predator of thrips and possessed positive correlation with thrips incidence. 


\section{References}

Anonymous, 2001. Studies on seasonal incidence of onion thrips. Annual Report. National Researchfor onion, Garlic, Nashik, pp. 65-66.

Chhatrola, D.P., Vyas, H.J. and Baraiya K.P. 2003. Influence of abiotic factor on population buildup of thrips, T. tabaci Lindeman in garlic. Madras Agricultural Journal, 80: 53-54.

Domiciano, N.L., Ota, A.Y. and Tendari, C.R. 1993. Population fluctuations of thrips on onion, its association with climatic elements and control, Anais $d a$ Sociedade Entomologicado Brazil, 22: 77-83.

Ghosh, S.K.; Laskar, N. and Senapati, S.K. 2005. Seasonal fluctuation in the population of thrips, T. tabaci Lindemanin the tarai region of west Bengal and its control on brinjal. Pest Management and Economic Zoology, 13: $185-190$.

Gomez K. A. and Gomez A. A. 1976, Problem data, Ststistical Procedures for Agriculture Research (II Ed), Jhon Wiley and sons, New York, pp 272-315.

Kadri, S. and Gaud, K.B. 2005. Survey and seasonal incidence of onion thrips, $T$. tabaci L. Karnataka Journal of
Agricultural Science, 18: 510-512

Kumar, A. 2016. Evalution of onion genotypes against onion thrips, $T$. tabaci Lindeman and its management through botanicals, M.Sc. Thesis. Indra Gandhi Krishi Vishwavidyalaya: Campus- Raipur (Chhattisgarh).

Kumawat, K. 2009. Eco-friendly management of Thrips, T. tabaci L. on onion, M.Sc. Thesis, S.K. Rajasthan Agriculture University: Campus- Jobner, pp.17.

Neergude, N., Biradar, A.P., Veerendra, A.C. and Ravulapenta, S. 2014. Seasonal abundance of onion thips, T. tabaci Lindeman and Their Natural enemies under Dry land conditions. International Journal of Advances in Pharmacy, Biology and Chemistry, 3(1): 33-36.

Swami, H., Mahla, M. K. and Nagar, K.C. 2013. Population dynamics of thrips on onion in sub-humid agro ecosystem of Rajasthan. Indian Journal of Applied Entomology, 27 (2): 140-142.

Waiganjo, M.M., Gitonga, L.M. and Mueke, J.M. 2008. Effects of weather on thrips population dynamics and its implications on the thrips pest management. Afr. J. Hort. Sci., 1: 8290.

\section{How to cite this article:}

Deepika Yadav, S.K. Khinchi, Purushotam Sharma and Hitesh Jangir. 2019. Seasonal Abundance of Thrips, Thripstabaci Lindeman and its Natural Enemies on Kharif Onion. Int.J.Curr.Microbiol.App.Sci. 8(02): 1476-1479. doi: https://doi.org/10.20546/ijcmas.2019.802.171 